\title{
Diversity and Continuity in Conversation Analysis
}

Nielsen, Mie Femø; Wagner, Johs.

Published in:

Journal of Pragmatics

DOI:

10.1016/j.pragma.2006.07.005

Publication date:

2007

Document version

Publisher's PDF, also known as Version of record

Citation for published version (APA):

Nielsen, M. F., \& Wagner, J. (2007). Diversity and Continuity in Conversation Analysis. Journal of Pragmatics, 39(3), 441-444. https://doi.org/10.1016/j.pragma.2006.07.005 


\section{Guest editorial \\ Diversity and continuity in conversation analysis}

This Special Issue of the Journal of Pragmatics presents a collection of studies of Conversation Analysis, which exemplify both the continuity of this line of research on talk-in-interaction and the growing diversity of research questions since its beginning in the mid 60s. As is widely known, Conversation Analysis (CA) emerged as a critical approach to sociology designed to study how members of a society create social order and meaning in their (mundane) interactions in real time. Based on audio- and video-recordings, CA studies how participants in interaction methodically create social structure and intersubjectivity-which makes CA different from a full-blown real time analysis as practised in ethnomethodology (Garfinkel, 1967; Heritage, 1984).

Two ground-breaking papers by Sacks et al. (1974), and Schegloff et al. (1977), set the agenda for a field which has quickly developed from its origin in sociology to influence many disciplines in Human Studies. The research focus of Conversation Analysis has also widened considerably. CA's first research object was mundane everyday conversation-hence the name Conversation Analysis. However, it should be noted that, although many of the initially available data were talks in the private sphere (e.g. the $N B$ corpus of private telephone calls between residents of a Californian beach town or the auto discussion, a neighborhood backyard meeting, videotaped by Charles Goodwin), institutional data were already available from the very beginning of CA (e.g. the suicide helpline data, the GTS therapy data). All these data sets were highly relevant for the formation of the academic community, as they were available to most of the researchers of the 'first generation' (Lerner, 2004), and served as a common denominator.

Drew and Heritage's edited volume 'Talk at Work' (1992) established institutional talk as an analytical phenomenon. CA studies of interactions in institutional settings demonstrate how social order is built and recognized in the talk between 'clients' and 'representatives' of an institution. Drew and Heritage (1992:4) indicate the impact of their collection themselves: the contributions to the book study different institutional domains and create a coherent research perspective thanks to their joint methodological basis in CA. In the last 20 years, the number of studies of institutional interaction has increased significantly, as can be seen from studies of medical interactions (Heritage and Maynard, 2006), interaction in high-tech environments (Suchman, 1987; Heath and Luff, 2000; Neville, 2004), news interviews (Clayman and Heritage, 2002), standardized survey interviews (Houtkoop-Steenstra, 2000), and negotiation (Firth, 1995), to mention but a few.

In the mid 90s, CA seriously branched out into other academic fields, most notably linguistics (Ochs et al., 1996; Ford and Wagner, 1996; Couper-Kuhlen and Selting, 1996; Selting and Couper-Kuhlen, 2001; Ford et al., 2002). This diversification even resulted in the establishment 
of a novel sub-field called 'Interactional Linguistics'. A forerunner of this branching out into different fields was Moerman's contribution to anthropology (Moerman, 1988). Today, CA has contributed significantly to disciplines as various as semiotics, communication, linguistics, psychology, anthropology, ethnography, and sociology. CA has studied a wide range of topics in a wide variety of settings, e.g. medical communication, law, education, different types of therapy, media, and business communication. As Mey recently has put it nicely "there is more to Conversation Analysis than the study of turn-taking and its mechanisms (2006:1145)."

Although CA research has engaged in new topics, settings, and disciplines, it has kept its identity and has acted as a discipline in its own right with a well-defined methodology and a strong analytic tradition in which new studies are written. Studies are carefully crafted collections of cases, sometimes assembled over many years due to low frequency. The cases are the basis for and the proof of the description of the recipies for social actions described in the studies. Herein lies the core of CA: testable sequential description of social actions, carried out on the basis of data, which have not been elicited but collected in the field. Still, in terms of the academic world, CA has not flagged an identity of its own in traditional academic ways, for example by the founding of specific journals, by creating an academic association or by arranging regular conferences (however, see below). CA research is published in a very wide range of journals, CA papers are given at many different conferences in different fields, and an International CA Society still does not exist.

With respect to conferences, however, the situation has been changing. The contributions to this Special Issue were originally produced for the International Conference on Conversation Analysis (ICCA-02), which was held in Copenhagen in 2002. This was the first large international 'pure' CA conference and illustrated the diversity of CA research. The current Special Issue collects some of the papers from that conference to demonstrate not only the growth and diversity of CA, but also the important element of continuity in the CA tradition.

\section{Contributors}

Gail Jefferson's paper 'Preliminary Notes on Abdicated Other-Correction' adds to her study of repairs, which is at the core of CA research (Schegloff et al., 1977; Jefferson, 1974, 1983). To quote one of the anonymous reviewers:

"This is a very Jefferson-esque paper-one that examines very delicate interactional work that can be unpacked from what at first looks like a simple and uninteresting practice. In addition to the main findings, which furnish convincing evidence of a very elusive phenomenon, the paper, in passing, gives us a glimpse of several never before described phenomena such as the 'repair format for silly things' and the distinction between the repair of an item from a class (wrong name) and the repair of the item's class (person to venue)."

'A Tutorial on Membership Categorization' is Emanuel A. Schegloff's reading of two papers by Harvey Sacks, where Sacks developed the concept of 'Membership Categorization Device' (MCD). MCDs are often illustrated by Sacks' most famous example, 'The baby cried, the mommy picked it up'. Sacks asks why the mommy is understood to be the baby's mommy and not somebody else's. To explain this reading, Sacks developed MCD as a collection of categories and rules for their application.

In 'Lists As Embedded Structures and the Prosody of List Construction as an Interactional Resource', Margret Selting takes as her point of departure the concept of 'lists' as described by 
Jefferson (1990). On the basis of German data, Selting shows that lists occupy the middle of a tripartite structure. She distinguishes between 'open' and 'closed' lists on the basis of prosodic cues, and provides a closer description of open lists.

Charles Antaki's contribution, 'Mental-health Practitioners' Use of Idiomatic Expressions in Summarising Clients' Accounts', builds on earlier research on mundane conversation demonstrating the potential of idiomatic expressions to close down topics (Drew and Holt, 1988). Therapists exploit these potentials to shut down client's talk and to move on in the therapy.

The contribution by Ray Wilkinson, 'Managing Linguistic Incompetence as a Delicate Issue in Aphasic Talk-In-Interaction: On the Use Of Laughter in Prolonged Repair Sequences' looks at interaction between speakers with aphasia and their conversation partners. Due to their condition, aphasic speakers encounter difficulties in producing language and cannot always avoid displays of linguistic incompetence. Wilkinson shows how aphasic speakers react to their display of incompetence by laughter or humorous noticings and under what conditions their conversational partners join the laughter or not.

In her contribution 'Interviewers' Challenging Questions in British Debate Interviews', Sofie Emmertsen looks at turn-taking. She argues that debate interviews have become confrontational in the media, and she shows how confrontations are provoked by the moderators' challenging question. In their confrontational form, debate interviews make use of both an institutional and a conversational format for turn-taking.

The final contribution, by Mardi Kidwell and Don Zimmerman, 'Joint Attention as Action', describes how very young children engage other people by showing objects. These pre-linguistic children demonstrate that they can establish contact where further action by the other person is relevant. Kidwell and Zimmerman integrate verbal and visual activities by children and caregivers and demonstrate how interactional opportunities are created in the flow of the overall activity.

The collected papers in this Special Issue demonstrate the wide range of current conversation analytic research. However, it is not a representative sample, since a number of recent developments are not documented here, e.g. cross-linguistic studies and studies of second language talk (Gardner and Wagner, 2004). Furthermore, the large number of studies on gesture and multimodality are only represented in this issue by a single contribution, that of Kidwell and Zimmerman.

All contributions to this Special Issue share the methodology of CA and demonstrate continuity in the field, despite the wide range of topics. But they indicate a new academic continuity in CA as well — the second ICCA conference was held in Helsinki in spring 2006 and another is planned for Mannheim in 2010.

\section{References}

Clayman, Steven, Heritage, John, 2002. The News Interview. Cambridge University Press, Cambridge.

Couper-Kuhlen, Elizabeth, Selting, Margret (Eds.), 1996. Prosody in Conversation. Cambridge University Press, Cambridge.

Drew, Paul, Holt, Elizabeth J., 1988. Complainable matters: the use of idiomatic expressions in making complaints. Social Problems 35, 398-417.

Drew, Paul, Heritage, John (Eds.), 1992. Talk at Work. Cambridge University Press, Cambridge.

Firth, Alan (Ed.), 1995. The Discourse of Negotiation. Pergamon Press, Oxford.

Ford, Cecilia E., Wagner, Johannes (Eds.), 1996. Special Issue: Interaction-based Studies of Language. Pragmatics 6.

Ford, Cecilia, Fox, Barbara A., Thompson, Sandra A. (Eds.), 2002. The Language of Turn and Sequence. Oxford University Press, Oxford. 
Garfinkel, Harold, 1967. Studies in Ethnomethodology. Prentice Hall, Englewood Cliffs, NJ.

Gardner, Rod, Wagner, Johannes (Eds.), 2004. Second Language Conversations. Continuum, London.

Heath, Christian, Luff, Paul, 2000. Technology in Action. Cambridge University Press, Cambridge.

Heritage, John, 1984. Garfinkel and Ethnomethdology. Polity Press, Cambridge.

Heritage, John, Maynard Douglas, W. (Eds.), 2006. Communication in Medical Care: Interactions between Primary Care Physicians and Patients. Cambridge University Press, Cambridge.

Houtkoop-Steenstra, Hanneke, 2000. Interaction and the Standardized Survey Interview. Cambridge University Press, Cambridge.

Jefferson, Gail, 1974. Error correction as an interactional resource. Language in Society 3, 181-199.

Jefferson, Gail, 1983. On exposed and embedded correction in conversation. Studium Linquistik 14, 58-68 [Reprinted in Button, G., Lee, J.R.E. (Eds.), 1987. Talk and Social Organization. Multilingual Matters: Clevedon, UK]

Jefferson, Gail, 1990. List construction as a task and interactional resource. In: Psathas, G. (Ed.), Interactional Competence. University Press of America, New York, pp. 63-92.

Lerner, Gene H. (Ed.), 2004. Conversation Analysis: Studies from the First Generation. Benjamins, Amsterdam. Mey, Jakob L., 2006. Editorial. Focus-on issue: discourse and conversation. Journal of Pragmatics 38, $1145-1146$.

Moerman, Michael, 1988. Talking Culture. Ethnography and Conversation Analysis. University of Pennsylvania Press, Philadelphia.

Neville, Maurice, 2004. Beyond the Black Box: Talk-in-Interaction in the Airline Cockpit. Ashgate Publishing Limited, Aldershot, UK.

Ochs, Elinor, Schegloff, Emanuel A., Thompson, Sandra A. (Eds.), 1996. Interaction and Grammar. Cambridge University Press, Cambridge.

Sacks, Harvey, Schegloff, Emanuel A., Jefferson, Gail, 1974. A simplest systematics for the organization of turn-taking in conversation. Language 50 (4), 696-735.

Schegloff, Emanuel A., Jefferson, Gail, Sacks, Harvey, 1977. The preference for self-correction in the organization of repair for conversation. Language 53, 361-382.

Selting, Margret, Couper-Kuhlen, Elizabeth (Eds.), 2001. Studies in Interactional Linguistics. Benjamins, Amsterdam. Suchman, Lucy A., 1987. Plans and Situated Actions: The Problem of Human-Machine Communication. Cambridge University Press, New York.

\title{
Mie Femø Nielsen \\ Department of Scandinavian Studies and Linguistics, University of Copenhagen, Njalsgade 120, DK-2300 Copenhagen S, Denmark
}

\author{
Johannes Wagner* \\ University of Southern Denmark, \\ Department of Business Communication and \\ Information Technology, Engstien 1, DK 6000 Kolding, Denmark \\ *Corresponding author. Tel.: +45 65501445 \\ E-mail addresses: femoe@hum.ku.dk (M.F. Nielsen) \\ jwa@sitkom.sdu.dk (J. Wagner)
}

